\title{
On-Farm Drip Irrigation in Rice for Higher Productivity and Profitability in Haryana, India
}

\author{
Rajeev Bansal ${ }^{1}$, Neeraj Sharma ${ }^{2}$, P. Soman ${ }^{3}$, Sarvan Singh ${ }^{3}$, \\ A.K. Bhardwaj ${ }^{4}$, T. Pandiaraj ${ }^{*}$ and R.K. Bhardwaj ${ }^{4}$ \\ ${ }^{1}$ Chief Engineer, Command Area Development Authority, Haryana, Bays No. 39-40, \\ Sector-4, Panchkula, Haryana, India \\ ${ }^{2}$ Executive Engineer, Command Area Development Authority, Kurukshetra, Haryana, India \\ ${ }^{3}$ Jain Irrigation System Ltd. Jalgaon, India \\ ${ }^{4}$ GBPUAT, Pantnagar, India \\ *Corresponding author
}

\section{A B S T R A C T}

\begin{tabular}{|l|}
\hline Ke y w o r d s \\
$\begin{array}{l}\text { Drip, Flood irrigation, } \\
\text { Return, Sprinkler, } \\
\text { Transplanted rice, } \\
\text { Yield }\end{array}$ \\
\hline Article Info \\
\hline $\begin{array}{l}\text { Accepted: } \\
\text { 07 January } 2018 \\
\text { Available Online: } \\
\text { 10 February } 2018\end{array}$ \\
\hline
\end{tabular}

Keywords

Drip, Flood irrigation, Return, Sprinkler, Yield

\section{Introduction}

Rice (Oryza sativa L.) is the most vital staple food crop in Asia and human consumption accounts for $85 \%$ of total production of rice and it ought to have a special status among cereals as world's most important crop (FAO, 2010). Given its burgeoning population growth, India should be producing 1.7 million $\mathrm{t}$ of additional rice every year to ensure national food security (Dass and Chandra, 2013). Consequently, there is a need to increase sustainably higher yields and productivity of rice cultivation, doing this to the extent possible with reduced inputs and with less exploitation of natural resources to feed the increasing global population. This is a challenge for rice-growing countries around the world.

For producing rice at present with traditional irrigation techniques, large quantities of water are being used to flood paddy fields with standing water $2-5 \mathrm{~cm}$ deep at the different stages of crop growth. Studies have indicated that 3.0 to $5.0 \mathrm{~m}^{3}$ of water are often used to produce $1 \mathrm{~kg}$ of rice (Satyanarayana et al., 2007), but this includes water applications which are clearly excessive. Water requirements for flooded rice production are 
now considered to average a little over 1.40 $\mathrm{m}^{3}$ per $\mathrm{kg}$ of rice. This is about three times more than for growing wheat and maize (Riaz, 2001). This will inexorably affect farming system of irrigated regions in future, especially irrigated for rice production. Further, traditional rice production system not only leads to wastage of water but also causes environmental problems and reduces nutrient use efficiency. Hence, an attempt to increase water productivity either by reducing water consumption or by increasing the yields will automatically facilitate higher growth in agricultural production. Micro irrigation through the trickle supply of water drops and or sprinkler systems holds promise in this respect. Micro Irrigation System (MIS) coming strongly as effective system for irrigating the paddy crop with more efficient in water use as well as more environment friendly in operation and management. With MIS system we can move towards "more crop per drop" (Soman, 2012).

Studies of water usage of many field crops, such as grapes, cotton, and tomatoes, suggest that different modes of irrigation significantly affect crops growth and WUE, with higher water productivity and higher crop yield obtained under micro irrigation than under traditional irrigation (Malash et al., 2008). In addition, there is little information regarding whether rice has higher grain yield and WUE under drip irrigation than under traditional irrigation, or whether rice cultivation with drip irrigation has superior grain production potential than that of existing rice water saving technologies.

On the other hand, conventional fertilization particularly on light soils may cause huge nutrient losses through leaching, percolation and volatilization. The greatest nitrogen loss in a rice field is in the range $20-45 \%$ through the process of volatilization and denitrification and 30-49\% through leaching into ground water (Kyuma, 2004). Precision N management through fertigation with drip irrigation can reduce overall fertilizer application rates and minimize adverse environmental impact. Researchers have demonstrated drip-irrigated crop response to $\mathrm{N}$ fertilizer with higher water use efficiency (Hanson and May, 2004; Wang et al., 2009). The limited information is available on use of drip irrigation on improvement of rice production and resource use efficiency. Taking these points into account an on farm trial was conducted to evaluate the effects of micro irrigation as compared with traditional flood irrigation on yield, water use efficiency and economics of rice.

\section{Materials and Methods}

The on farm trial was conducted in the farmer Sardar Karanjeet Singh field of Gumthala Garhu village of Kurukshethra district Haryana state . The experimental site is situated of Latitude $30^{\circ} 75^{\prime} \mathrm{N}$ and Longitude $76^{\circ} 78^{\prime} \mathrm{E}$ at an altitude of $260 \mathrm{~m}$ above mean sea level (MSL). Soil type of the experimental field is clay loam. Monsoon starts at the end of June and extends upto September. The annual rainfall of the region is $720 \mathrm{~mm}$. average $81 \%$ of annual rainfall provides fair amount of water in the South West Monsoon. The total rain received during cropping period was 337 $\mathrm{mm}$ and effective rainfall is $167 \mathrm{~mm}$. The rainfall distribution is depicted in Figure 1. The summer months from March to May are very hot and humid.

\section{Irrigation treatments}

Field experiment was adopted using PR 126 of rice as the test variety. In this study, three different irrigation systems were used. These are drip, sprinkler and traditional flood systems. The irrigation treatments were based on average water requirement of rice crop upon soil moisture condition. The drip 
irrigation was given through PVC pipe after filtering through the screen filter by $7.5 \mathrm{HP}$ motor from the bore well. The pressure maintained in the system was $1.2 \mathrm{~kg} \mathrm{~cm}^{-2}$. From the sub-main, in-line laterals were laid out of $16 \mathrm{~mm}$ at a spacing of $0.6 \mathrm{~m}$ with 2.4 lph discharge rate emitter position at a distance of $40 \mathrm{~cm}$. A line source of sprinkler irrigation System was used for sprinkler irrigation. The sprinkler heads were located at $10 \mathrm{~m}$ intervals on the lateral pipe and total number of sprinkler was 56 with part cycle for one acre land area. The flood irrigation was maintained at $5.0 \mathrm{~cm}$ water depth.

The urea as nitrogen and muriate of potash (MOP) as potash source of fertilizers were applied through fertigation under drip and sprinkler systems whereas Single Super Phosphate (SSP) and Zinc fertilizers were applied through soil application during the sowing time. In flood irrigation method, all fertilizers had applied broadcasting; in which, half dose of $\mathrm{N}$, full dose of $\mathrm{P}$ and $\mathrm{K}$ fertilizers were applied through basal application and remaining half dose of $\mathrm{N}$ fertilizers applied through top dressing. The fertigation details are given in Table 1.

\section{Results and Discussion}

\section{Rice grain yield}

According to the results of this on-farm experimental study, rice yields ranged from $4800 \mathrm{~kg} \mathrm{ha}^{-1}$ to $6950 \mathrm{~kg} \mathrm{ha}^{-1}$ under transplanted rice of different irrigation systems. As seen from Figure 2, each irrigation methods produced different rice yields. The drip irrigation method resulted in a higher grain yield than that of either the sprinkler or flood method. This yield diversity is statistically significant. Considering the maximum yields, drip irrigation produced $11.65 \%$ more grain yield as compared to flood irrigation method, and $44.79 \%$ more than the sprinkler method. Hence, drip irrigation resulted in not only higher grain yield but also substantial input source saving such water and nutrient. Drip irrigation is facilitating continuous availability of water to the plant roots vicinity and thus plant always be growing with optimum soil moisture and proper aeration in soil resulted in higher root growth and grain yield. These findings are consistent with the results reported by Yang et al., (2004) indicating that intermittent irrigation and maintaining moist, mostly aerobic soils not only enhances yield characters but also the root system's development and functioning. These results were in accordance with the study of Viraktamath (2006) and Soman (2012). Further, lower yield with sprinkler irrigation may be the impact of the sprinkler drops on the flower and the burning of the flowers and leaves by sunshine due to the lens effect resulted in low spikelets and eventually low yield. The same result is also corroborated with the finding of Kadiyala et al., (2012).

\section{Water use studies}

The total water use and water use efficiencies under flood, drip and sprinkler methods of irrigation are presented in Table 2. The total water use inclusive of effective rainfall in flood irrigation of farmers practice was 587.4 $\mathrm{mm}$ whereas it was only $407.3 \mathrm{~mm}$ and 419 $\mathrm{mm}$ in drip and sprinkler irrigation methods, respectively.

This resulted in 30.7 and 28.7 per cent of water saving under drip and sprinkler methods, respectively as compared to flood practice. The drip irrigation methods used less water due to restriction of water loss through evaporation from large amount of ground, conveyance losses resulted in maximum water use by crops. Similar result of water saving under drip irrigation was pointed out by Veeraputhiran (2000). 
Fig.1 Annual rainfall as received during the experimental period in 2017

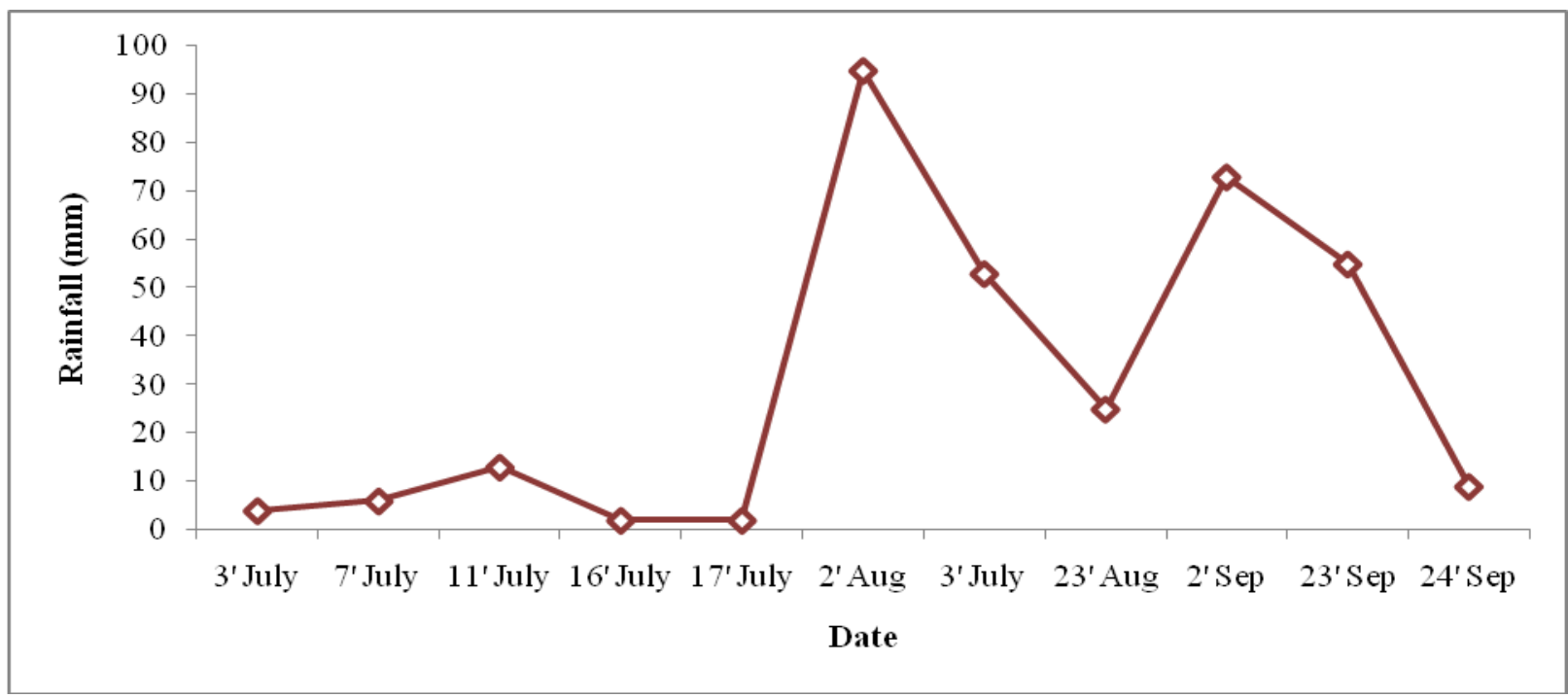

Fig.2 Grain yield of on-farm trial rice $\left(\mathrm{kgha}^{-1}\right)$ as influenced by different irrigation methods. Treatments means followed by common letter (s) are not significantly different among each other according to LSD test

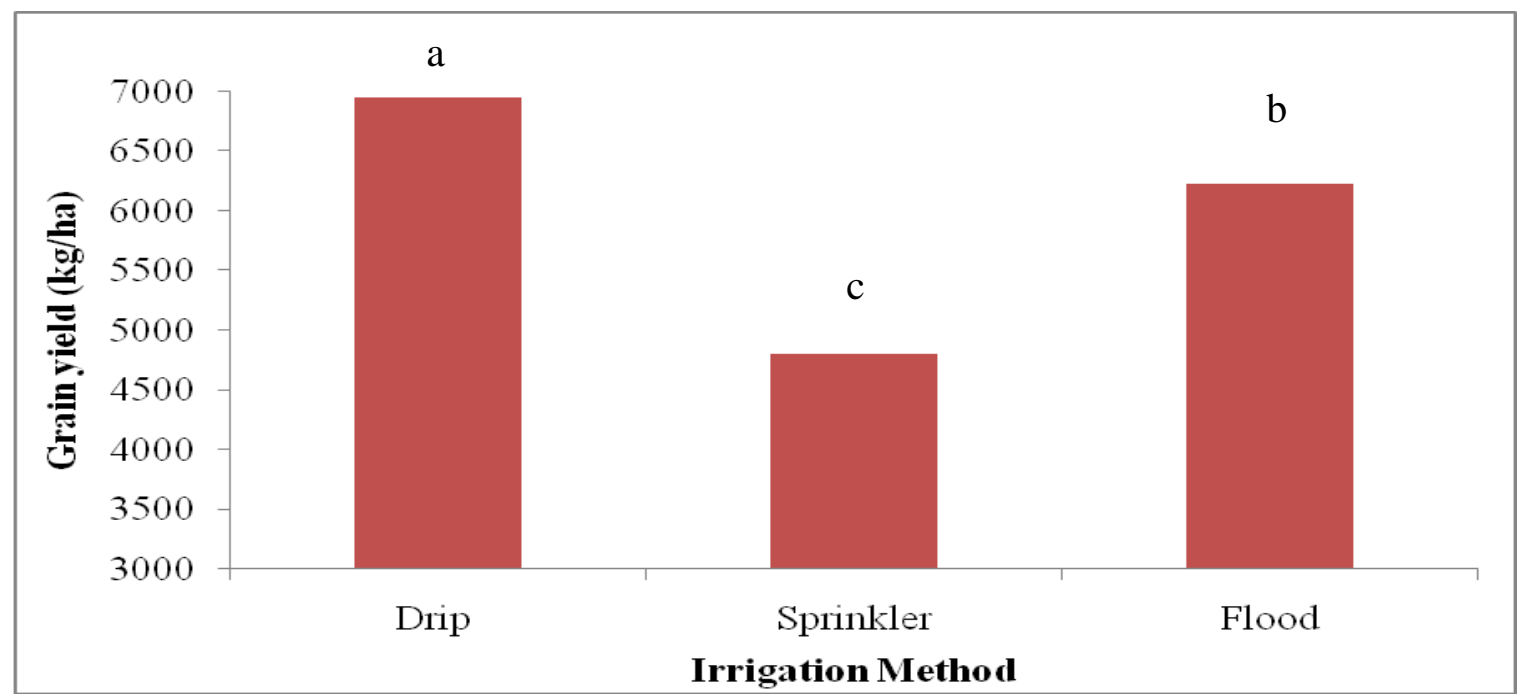

Table.1 Fertigation schedule followed for experimental transplanted rice under drip and sprinkler irrigation method

\begin{tabular}{|c|c|c|c|c|c|}
\hline Schedule of Fertigation & Urea $(\mathrm{kg})$ & SSP $(\mathrm{kg})$ & MOP(kg) & Zn $(\mathrm{kg})$ & Fertilizer rate per day \\
\hline Basal (soil application) & 0 & 150 & 0 & 10 & $3.5 \mathrm{~kg}$ urea/day \\
\hline 10-20 DAT (Fertigation) & 35 & 0 & 0 & & $2.08 \mathrm{~kg}$ urea/day \\
\hline 21-40 DAT (Fertigation) & 52 & 0 & 0 & & 650 gram urea/day \\
\hline 41-60 DAT (Fertigation) & 13 & 0 & 15 & & 750 gram urea/day \\
\hline 61-80 DAT (Fertigation) & 0 & 0 & 10 & & 500 gram urea/day \\
\hline
\end{tabular}


Table.2 Total water use and water use efficiency (WUE) $\left(\mathrm{kg} \mathrm{hamm}^{-1}\right)$ under micro and flood irrigation methods

\begin{tabular}{|l|c|c|c|c|c|}
\hline \multicolumn{1}{|c|}{ Treatments } & $\begin{array}{c}\text { Irrigation } \\
\text { water applied } \\
(\mathbf{m m})\end{array}$ & $\begin{array}{c}\text { Effective } \\
\text { rainfall } \\
(\mathbf{m m})\end{array}$ & $\begin{array}{c}\text { Total water } \\
\text { used }(\mathbf{m m})\end{array}$ & $\begin{array}{c}\text { Per cent saving } \\
\text { of water over } \\
\text { flood irrigation }\end{array}$ & $\begin{array}{c}\text { WUE } \\
\left(\mathbf{k g ~ h a ~} \mathbf{~ m m}^{-1}\right)\end{array}$ \\
\hline Drip Irrigation & 240.0 & 167.0 & 407.3 & 30.7 & 17.1 \\
\hline Sprinkler irrigation & 252.0 & 167.0 & 419.0 & 28.7 & $\mathbf{1 1 . 5}$ \\
\hline Flood Irrigation & $\mathbf{4 2 0 . 4}$ & $\mathbf{1 6 7 . 0}$ & $\mathbf{5 8 7 . 4}$ & - & $\mathbf{1 0 . 6}$ \\
\hline
\end{tabular}

Table.3 Economic and monetary benefits of rice cultivation with micro irrigation systems over conventional system

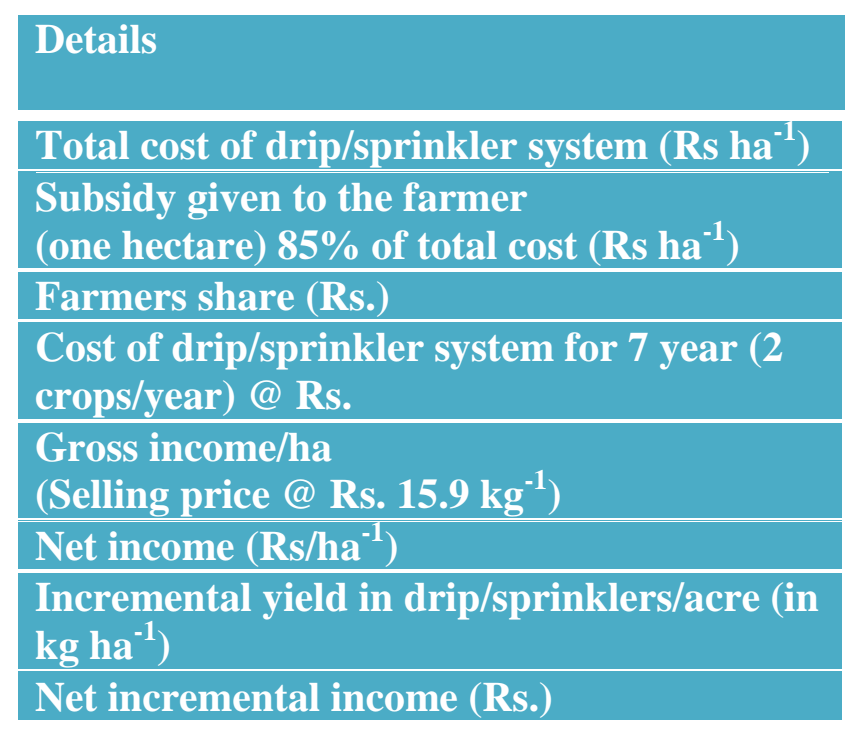

The paddy crop grown through drip irrigation was registered higher WUE $\left(17.1 \mathrm{~kg} \mathrm{ha} \mathrm{mm}^{-1}\right)$ while low level of WUE $\left(10.6 \mathrm{~kg} \mathrm{hamm}^{-1}\right)$ was found in flood irrigation. The WUE of sprinkler method was $11.5 \mathrm{~kg}$ ha mm $\mathrm{mm}^{-1}$ in transplanted paddy crop. Adequate and timely availability of water, nutrients and their synergistic interaction had stimulated to record higher water use efficiency under drip fertigation (Veeraputhiran, 2000).

\section{Monetary benefits}

In the present study, the monetary benefits of rice crop under micro irrigation i.e. drip and sprinkler methods were compared with flood irrigation method. The annual cost of drip

\begin{tabular}{|c|c|c|}
\hline $\begin{array}{c}\text { Transplanted } \\
\text { Drip }\end{array}$ & $\begin{array}{c}\text { Transplanted } \\
\text { Sprinkler }\end{array}$ & $\begin{array}{c}\text { Transplanted } \\
\text { Flood }\end{array}$ \\
\hline 125000 & 100000 & - \\
\hline 106250 & 85000 & - \\
\hline 18750 & 15000 & - \\
\hline 1337.5 & 1072.5 & - \\
\hline 110505 & 76320 & 98977 \\
\hline 84467 & 50572 & 74277 \\
\hline 725 & No & - \\
\hline 11277 & No & - \\
\hline
\end{tabular}

irrigation system was calculated with the assumption that the life micro irrigation system infrastructure would be 07 years with 07-10 per cent annual depreciation. The cost components considered included land preparation, seeds, fertilizer, labour, harvesting and threshing. Uniform cost values were considered for all irrigation method. The drip fertigation system has been found more profitable than sprinkler and flood irrigation due to higher yield. The finding of the study indicated that the higher net return (Rs.33787 per acre) was obtained under drip irrigation method followed by flood irrigation method of irrigation (Rs. 29711 per acre). The lowest net return (Rs.20229 per acre) was in sprinkler irrigation method (Table 3). It 
showed that drip irrigation produced $12 \%$ more net income than flood irrigation method, and $40 \%$ higher net income as compared to sprinkler irrigation system. Further, drip irrigation system proved $0.29 \mathrm{t}$ higher incremental yield than any other method. Similarly, net increment income of drip irrigation system was Rs. 4511 over traditional flood irrigation method. Richakhanna (2013) reported that optimal water use can enhance returns with enhanced labour productivity and far higher net income than traditional methods for the cultivation of rice. These results were in agreement with the findings of Veeraputhiran et al., (2002), Soman (2012) and Abdelraouf et al., (2013).

The present study concluded that irrigation through drip system along with fertilizer applications recorded higher grain yield and WUE in transplanted paddy crop. However, these results should further be tested with advanced experimentation and evaluation because the implications of this work could be rather far-reaching. The evidence assembled and analyzed here suggests that transplanted rice cultivation with drip irrigation is a hopeful adaptation for reducing the ricecrop's demand for water and nutrient, which are increasingly demanded and costly, while at the same time it raises grain yield. Further, long term and multi-location trials will be needed to arrive at percentages of water and nutrient saving that are realizable under different and specific situation.

\section{References}

Abdelraouf RE, Habbasha S, Taha MH, Refaie KM 2013. Effect of irrigation water requirements and fertigation levels on growth, yield and water use efficiency in wheat. Middle-East $\mathrm{J}$ Scientific Res 16: 441-450.

Dass, A., Chandra, S. 2013. Irrigation, spacing and cultivar effects on net photosynthetic rate, dry matter partitioning, and productivity of rice under system of rice intensification in mollisols of northern India. - Expl. Agri. 49(4): 504-523.

FAO (Food and Agriculture Organization of the United Nations), 2010. Electronic on-line database. Online at http://www.fao.org

Hanson, R., and D May 2004. Effect of subsurface drip irrigation on processing tomato yield, water table depth, soil salinity and profitability, Agricultural Water Management, 68, pp. 1-17.

Kadiyala, M.D., R S Mylavarapu, Y C Li, G B Reddy, and M D Reddy 2012. Impact of Aerobic Rice Cultivation on Growth, Yield, and Water Productivity of RiceMaize Rotation in Semiarid Tropics, Agronomy Journal, 104, 6, pp. 17571765.

Malash NM, Flowers TJ, Ragab 2008. Effect of irrigation methods, management and salinity of irrigation water on tomato yield, soil moisture and salinity distribution. IrrigatSci 26: 313-323. K Kyuma (2004), Paddy soil science, Kyoto University Press, Kyoto, Japan 280 pp., 2004.

Riaz, A. 2001. Crop Management in Pakistan. - Department of Agriculture, Government of Punjab, Lahore.

Richakhanna 2013. Effect of precision nutrient and water management with different sources and levels of fertilizers on rice production.

Satyanarayan, A., Thiyagarajan, T.M., Uphoff, N. 2007. Opportunities for water saving with higher yield from the system of rice intensification. Irrigation Science 25:99-115.

Soman, P. 2012. Drip irrigation and fertigation technology for Rice cultivation. - Paper presented at the ASIAN IRRIGATION FORUM; held at Asian Development Bank, Manila, 11- 
13, April 2012, ADB, Manila, Phillippines.

Veeraputhiran R, Kandasamy OS, Singh SSD 2002. Effect of drip irrigation and fertigation on growth and yield of hybrid cotton. J AgricReso Manage 1: 88-97.

Veeraputhiran, R. 2000. Drip fertigation studies in hybrid cotton. Ph.D. Thesis. Tamil Nadu Agricultural University, Coimbatore.

Viraktamath BC 2006. Evaluation of system of rice intensification (SRI) under All India Coordinated Rice Improvement Project. In: Abstracts of Nat Symposium on System of Rice Intensification (SRI)—Present status and future prospects. 17-18.pp. 1113.

Wang, Z., L Zuoxin, Z Zikun and L Xingbin 2009. Subsurface drip irrigation scheduling for cucumber (Cucumis sativus L.) grown in solar greenhouse based on $20 \mathrm{~cm}$ standard pan evaporation in Northeast China, Scientia Horticulturae, 123, 1, pp. 5157.

Yang, C., Yang, L., Yang, Y. Ouyang, Z. 2004. Rice root growth and nutrient uptake as influenced by organic manure in continuously and alternatively flooded paddy land. - Agric. Water Manage. 70(1): 67- 81 .

\section{How to cite this article:}

Rajeev Bansal, Neeraj Sharma, P. Soman, Sarvan Singh, A.K. Bhardwaj, T. Pandiaraj and Bhardwaj, R.K. 2018. On-Farm Drip Irrigation in Rice for Higher Productivity and Profitability in Haryana, India. Int.J.Curr.Microbiol.App.Sci. 7(02): 506-512.

doi: https://doi.org/10.20546/ijcmas.2018.702.064 